\title{
Üniversite Öğrencilerinin Sosyal Girişimcilik Eğilimleri: Beden Eğitimi ve Spor Yüksekokulu Örneği ${ }^{1}$
}

\author{
Yeliz ERATLI ŞIRIN
}

\author{
Fatma Pervin BíLiR ${ }^{2}$
}

\author{
Günseli ÖZ ${ }^{3}$
}

\footnotetext{
${ }^{2}$ Çukurova Üniversitesi, Beden Eğitimi ve Spor Yüksekokulu, ADANA

${ }^{3}$ Doğa Koleji Okulları, KAHRAMANMARAŞ
}

Künye: Şirin, Y.E., Bilir, F.P. ve Öz, G. (2018). Üniversite Öğrencilerinin Sosyal Girişimcilik Eğilimleri: Beden Eğitimi ve Spor Yüksekokulu Örneği. Gaziantep Üniversitesi Spor Bilimleri Dergisi, 3(3): 35-47.

\section{Öz}

Üniversite öğrencilerinin sosyal girişimcilik düzeylerini belirlemek ve sosyal girişimcilik alt boyutları olan; risk alma, özgüven ve kişisel yaratıcılık eğilimlerinin demografik değişkenler açısından incelenmesi bu çalışmanın amacını oluşturmaktadır. Çalışmaya Kahramanmaraş Sütçü İmam Üniversitesi Beden Eğitimi ve Spor Yüksekokulunda (BESYO) okuyan 230 öğrenci (121 kadın 129 erkek) gönüllü olarak katılmıştır. Araştırmada veri toplama aracı olarak Konaklı ve Göğüş (2013) tarafından geliştirilen "Sosyal Girişimcilik Ölçeği" ve "Kişisel bilgi formu" kullanılmıştır. Araştırmada bağımsız iki grup karşılaştırmalarında T-testi, bağımsız ikiden fazla grubun karşılaştırılmasında Anova testi kullanılmıştır. Çoklu karşılaştırmalarda farklıığın kaynağını bulmak için Bonferroni testinden yararlanılmıştır. Araştırmanın sonucunda üniversite öğrencilerinin sosyal girişimcilik eğilimlerinin olumlu yönde olduğu bulunmuştur. Alt boyutlarla; cinsiyet, anne ve baba eğitim durumu değişkenleri arasında anlamlı farklılık belirlenmiştir $(p<0.05)$. Üniversite öğrencilerinin, sosyal girişimcilik eğilimlerinin olumlu olduğu ve bazı demografik özelliklere göre farklıık gösterdiği ifade edilebilir.

Anahtar Kelimeler: Girişimcilik, Sosyal girişimcilik, Beden eğitimi ve spor

\section{Orijinal Makale}

\section{Yayın Bilgileri}

Gönderi Tarihi: 03.07.2018

Kabul Tarihi: 05.09.2018

Yayın Tarihi: 24.09.2018

\section{Sorumlu Yazar}

e-mail: yelizsirin75@gmail.com

DOI: $10.31680 / g a u n j s s .439956$

\section{Universty Students Social Entrepreneurship Trends: The Example of School of Physical Education and Sport}

\begin{abstract}
The aim of this study is to determine the level of the social entrepreneurship of the Physical Education Department and Sport High School students and analyzing tendency for risk-taking, self-confidence and personal creativity according to demographic variables. The data has been collected from 230 students (121 female,129 male) that attend to Students Physical Education Department and Sport High School Kahramanmaraş Sutcu Imam University. As the data collection device for the study "Social Entrepreneurship Scale" reformed by Konaklı and Göğüs (2013) and to determine the demographic characteristics of the students, "Personalin formation form" have been used. T-test test is applied to compare two independent groups, Anovo analysis is applied to compare more than two independent groups in the study. The Bonferroni test was used to find the source of the difference in multiple comparisons. . The result of the research of university students is a positive trend of social entrepreneurship According to the findings, it is found out that there is significant difference between the sub dimensions of the students' social entrepreneurship and gender, mother's educational statues and father's educational statues $(p<0.05)$. It has been reached that the level of social entrepreneurship of the sports department students is high and it differs according to some demographic characteristics.
\end{abstract}

\section{Original Article}

\section{Article Info}

Received: 03.07.2018

Accepted: 05.09.2018

Published: 24.09.2018

\section{Corresponding Author}

e-mail: yelizsirin75@gmail.com

Key Words: Entrepreneurship, Social entrepreneurship, Physical education and sports,

\footnotetext{
${ }^{1}$ Bu çalışma 15-18 Kasım 2017 Antalya'da düzenlenen 15. Uluslararası Spor Bilimleri Kongresinde Poster bildiri olarak sunulmuştur.
} 


\section{Giriş}

Girişimcilik (entrepreneurship) kavram olarak, bir girişimci olma eylemini ifade ederken, Fransızca'daki "üstlenmek-girişmek; fırsatları kovalamak; yenilik ve bir iş başlatma yoluyla gereksinim ve istekleri yerine getirmek" anlamına gelen "entreprendre" kelimesinden türetilmiştir (Dilsiz ve Kölük, 2008). Girişimcilik; yenilikçi, yaratıcı, risk alma, ürün, hizmet veya fikirlerin oluşturulmasını içerir ve fırsatları tanıma ve takip sürecidir (Gartner, 1988).Bir başka tanıma göre girişimcilik; birey ve toplum için değer yaratan, ekonomik fırsatlara cevap veren veya ekonomik fırsatlar yaratan bireyler tarafından ortaya konulan, getirdiği yeniliklerle ekonomik sistemde değişikliklere neden olan bir süreçtir (Yılmaz ve Sünbül, 2009). Girişimcilik ve sosyalliği içeren sosyal girişimcilik kavramı, toplumsal sorunları çözme doğrultusunda yapılan bir girişimcilik türü olarak ifade edilir (Gusseinova, 2015). Kar amacı gütmeyi öncelikli amaç olarak vurgulayan girişimcilik kavramının aksine sosyal girişimcilik, sosyal amaçlar doğrultusunda yenilik yaratarak sosyal dönüşümü sağlamayı amaçlamaktadır (Güler, 2010). Sosyal girişimcilik, sosyal sorunların farkında ve değişim yaratma amacında olan girişimcilerin, mevcut veya muhtemel sosyal sorunlara yönelik ürettikleri çözümlerin sosyal fayda oluşturma hedefiyle uygulanması sürecidir. Sosyal girişimciliğin temel amacı sosyal sorunları çözmek ve bu yolla sosyal kalkınmaya katkı sağlayarak toplumsal değişim yaratmaktır (Çoşkun ve Sarıkaya, 2016). Sosyal girişimcilik toplumsal değişimi, toplumsal değeri yaratmayı ya da toplumun intiyaçlarını karşılamak için yenilikçi kaynakları kullanma süreci" olarak tanımlanmıştır (Konaklı ve Göğüş, 2013).

Sosyal ve ekonomik girişimciler farklılık göstermekte ve ideolojilerinde misyon ve amaç seçimi bulunmaktadır. Sosyal girişimciler yenilikçi girişimsel organizasyonları veya yatırımları yönetirler ve temel misyonları kârdan ziyade sosyal değişim ve kendi müşteri kitlesinin gelişimidir. Sosyal girişimciler kâr-amaçlı girişimlerde de bulunabilir ancak, kârı kendilerini amaçlarına ulaştıracak bir araç olarak görürler (Özdevecioğlu ve Cingöz, 2009). Toplumda var olan sosyal sorunlar için yaratıcı çözümler üretmek, bu çözümleri gerçekleştirmek için uygun kaynakları oluşturmak, risk alarak bulunan çözümü hayata geçirmek ve hayata geçirilen çözümün sürekliliğini sağlayarak sosyal fayda oluşturmak sosyal girişimciliğin en temel amaçları olarak karşımıza çıkmaktadır (Çavuş, 2017).

Sosyal girişimciler, sosyal değer yaratma misyonlarını tamamlamak için yeni kaynak geliştirir, öğrenmeyi sürekli kılar, fırsat yaratır ve risk alarak fikirlerini 
gerçekleştirir. Yani, sosyal girişimciler de, tıpkı iç girişimciler gibi risk alarak yenilik veya geliştirme yapan kişilerdir. Burada ki en önemli nokta, hem iç girişimcilerin hem de sosyal girişimcilerin amaçlarına istedikleri doğrultuda ulaşabilmeleri için önemli derecede risk almalarıdır. Bunun nedeni bir iç girişimci başarılı olamadığı zaman işletmesi, kendi ve yakın çevresi zarar görürken, yaratıcılık özellikleri sayesinde toplumsal sorunlara yeni çözüm yolları üreten kişiler olan sosyal girişimci başarısız olduğunda ise sadece kendisi değil aynı zamanda toplum da zarar görecektir (Güven, 2013).

Toplumların içerisindeki sosyal sorunlara çözüm bulunmadığı takdirde toplumlarda bütünlük sağlanamaz ve bu durum toplumun geleceği için bir tehdit oluşturabilir. Ülkelerin ve toplumların geleceği olan gençlerin sosyal konulara karşı duyarlı olmaları ve sorunlara karşı çeşitli yaratıcı çözümler üretmeleri ve ürettikleri bu çözüm stratejilerinin topluma fayda sağlaması çok önemlidir. Bu çerçevede, sosyal girişimcilik sadece kurumsal değil aynı zamanda bireysel açıdan da dikkat çeken konulardan biri haline gelmiştir (Koçak ve Kavi, 2014). Sosyal girişimci, yaşadığı toplumda ortaya çıkan sosyal aksaklıkları fark ederek o güne kadar denenmemiş bir yaklaşım geliştirerek sorunların üzerine eğilen; yaratıcı, ısrarcı, duyarlı, gerçekçi tavırlarıyla fark yaratan ve toplumun güvenini kazanan kişi olarak tanımlanmaktadır (Denizalp, 2009) ve sosyal girişimcilik eğitimi bu özellikleri bireylere kazandırmak amaçlı uygulanan bir eğitim yaklaşımıdır (Çoşkun ve Sarıkaya, 2016). Son zamanlarda yapılan araştırmalar sonucunda girişimcilik eğilimlerinin bireysel tutumlar, geçmiş deneyimler, kişisel davranışlar (Baron, 2004); demografik kişisel ve çevresel etkenler gibi birçok faktörden oluştuğunu ortaya koymuştur (Linan ve Chen, 2009). Aynı zamanda liderlik yaratıcılık, motivasyon, yenilikçilik, risk alma, kendine güven ve öz yeterlik (Brown ark., 2011) girişimciliği etkileyen kişisel faktörler olarak sıralanmaktadır. Spor gittikçe büyüyen bir sosyal ekonomik fenomen olarak kabul edilmekte ve sağlığın iyileştirilmesi amacının ötesinde sosyal, kültürel ve eğlence amaçlı bir işlevi yerine getiren eğitimsel bir boyuta sahip olması sporda girişimcilik özelliklerini farklı boyutlara taşımaktadır. Sporda girişimcilik eğitimi, öğrencilere fırsatları belirleme, spor girişimlerini geliştirme veya mevcut bir spor organizasyonlarını geliştirme fırsatı sunarak öğrencileri, yeni veya mevcut iş, hayır kurumları, sivil toplum örgütleri, kamu sektörü ve sosyal işletmeler dahil olmak üzere spor alanındaki girişimcilik becerilerini ve niteliklerini spora uyarlamak için teşvik etmeye odaklanmalıdır (Nová, 2015). Türkiye'de eğitim alanında öğretmenler üzerine 
ve üniversite öğrencilerinin girişimcilik özelliklerini belirlemeye yönelik araştırmalar bulunmakla birlikte (Erdoğan ark., 2014; Çavuş ve Pekkan, 2017; İ̧can ve Kaygın, 2011; Uluyol, 2013) spor alanında girişimcilik özellikleri ile ilgili sınırlı sayıda çalışma bulunmaktadır (Geri, 2013; Nová, 2014; Özmen, 2015). Dolayısıyla çalışmanın beden eğitimi ve spor yüksek okullarında öğrenim gören beden eğitimi öğretmeni ve antrenör yetiştirme programlarında sosyal girişimcilik özelliklerinin dikkate alınması açısından alana katkı sağlaması beklenmektedir. Aynı zamanda BESYO öğrencilerinin atanma zorluklarından dolayı kendi işlerini kurma, özel sektörde veya başka iş alanlarında çalışma zorunluluğu doğmuş ve bu açıdan öğrencilerin girişimcilik özelliklerinin ortaya konması ve spor bölümü öğrencilerinin sosyal girişimcilik ruhunun gelişmesi açısından kavramsal bir çerçeve sunması araştırmanın önemini göstermektedir.

\section{Yöntem}

Araştırmanın bu bölümünde araştırmanın modeline, evren ve örneklemine, veri toplama araçlarına, verilerin toplanmasına ve çözümlenmesine ilişkin bilgilere yer verilmiştir.

\section{Araştırmanın Modeli}

Bu araştırma kapsamında Kahramanmaraş Sütçü İmam Üniversitesi Beden Eğitimi ve Spor Yüksekokulunda öğrenim gören öğrencilerin sosyal girişimcilik düzeylerinin belirlenmesi amaçlandığından araştırma betimsel bir çalışmadır.

\section{Evren ve Örneklem}

Araştırmanın grubunu, 2016-2017 eğitim öğretim yılında Kahramanmaraş Sütçü İmam Üniversitesi Beden Eğitimi ve Spor Yüksekokulu öğretmenlik ve antrenörlük bölümünde öğrenim gören 121 kadın, 109 erkek toplam 230 öğrenci oluşturmaktadır.

\section{Veri Toplama Araçları}

Araştırmada veri toplama aracı olarak Konaklı ve Göğüş (2013) tarafından geliştirilen "Sosyal Girişimcilik Ölçeği" ve araştırmacı tarafından hazırlanan "Kişisel bilgi formu" kullanılmıştır. Sosyal girişimcilik ölçeği 5'li Likert tipinde olup 3 alt boyuta sahiptir. Risk alma boyutu: 7 madde, kendine güven boyutu: 8 madde ve kişisel 
yaratıcılık boyutu 6 madde olmak üzere toplam 21 maddeden oluşmaktadır. Sosyal girişimcilik ölçeği için Konaklı ve Göğüş (2013) tarafından hesaplanan güvenilirlik düzeyleri ve araştırmamızda ölçek boyutları için bulunan güvenirlilik düzeyleri karşılaştırmalı olarak tablo 1 de gösterilmiştir sunulmaktadır.

Tablo 1. Sosyal Girişimcilik Ölçeği Boyutlarının Orijinal Araştırma ve Mevcut Araştırma Genelinde Karşılaştırılmalı Güvenirlik Düzeyleri (a değerleri)

\begin{tabular}{|c|c|c|}
\hline Boyutlar & $\begin{array}{l}\text { Orijinal Ölçek güvenirlilik } \\
\text { katsayıları }\end{array}$ & $\begin{array}{l}\text { Araştırma ölçek boyutları } \\
\text { güvenirlilik katsayıları }\end{array}$ \\
\hline Risk Alma & .716 & .81 \\
\hline Özgüven Boyutu & .767 & .87 \\
\hline $\begin{array}{l}\text { Kişisel Yaratıcılık } \\
\text { Boyutu }\end{array}$ & .70 & .82 \\
\hline
\end{tabular}

\section{Verilerin Analizi}

Çalışmanın istatistiksel analizlerinde, yüzde, frekans, aritmetik ortalama ve standart sapma gibi tanımlayıcı istatistikler kullanılmıştır. Araştırma verilerinin normal dağılış gösterip göstermediğini test etmek için Kolmogorov-Smirnov testi yapılmıştır ve verilerin dağılımının normal olduğu belirlenmiştir. Verilerin analizinde İkili karşılaştırmalarda T-testi, ikiden fazla grupların karşılaştııılmasında ise Anova testi, çoklu karşılaştırmalarda farklılığın kaynağını bulmak için Bonferroni testi kullanılmıştır.

\section{Bulgular}

Araştırmanın birinci problemi olarak "Öğrencilerin sosyal girişimcilik" düzeyleri ele alınmıştır. Öğrencilerin sosyal girişimcilik ölçeğine verdikleri cevapların ortalamalarına bakıldığında $(X=82.16, s s=12.95)$ olarak bulunmuştur. Madde bazında bakıldığında sosyal girişimcilik ortalaması (X=3.91) "Katılıyorum" - 4 (3.41- 4.20) aralığına denk gelmektedir. Bu sonuçlara göre öğrencilerin olumlu sosyal girişimcilik düzeyinde olduğu sonucuna ulaşılmıştır. 
Tablo 2. Öğrencilerin cinsiyet ve okudukları bölümlere göre Sosyal Girişimcilik alt boyutlarına ilişkin t-testi sonuçları

\begin{tabular}{|c|c|c|c|c|}
\hline Boyutlar & $\begin{array}{c}\text { Erkek }(n=121) \\
\bar{X} \pm S S\end{array}$ & $\begin{array}{c}\text { Kadın }(n=109) \\
\bar{X} \pm S S\end{array}$ & $\mathbf{t}$ & $\mathbf{p}$ \\
\hline Risk Alma & $27.64 \pm 4,98$ & $29.52 \pm 4.50$ & -3.0 & $0.003^{*}$ \\
\hline Özgüven & $30.77 \pm 5,52$ & $30.22 \pm 7.54$ & .62 & 0.530 \\
\hline Kişisel Yaratıcılık & $23.09 \pm 4,29$ & $23.13 \pm 4.96$ & -.06 & 0.950 \\
\hline Boyutlar & $\begin{array}{c}\text { Öğretmenlik (n=112) } \\
\bar{X} \pm S S\end{array}$ & $\begin{array}{c}\text { Antrenörlük (n=118) } \\
\bar{X}_{ \pm} \pm S\end{array}$ & $\mathbf{t}$ & $\mathbf{p}$ \\
\hline Risk Alma & $28.45 \pm 5.07$ & $28.61 \pm 4.63$ & -.24 & 0.810 \\
\hline Özgüven & $31.36 \pm 5.32$ & $29.71 \pm 7.46$ & 1.94 & 0.052 \\
\hline Kişisel Yaratıcılık & $23.41 \pm 4.31$ & $22.83 \pm 4.81$ & .94 & 0.340 \\
\hline
\end{tabular}

Tablo 2'ye göre öğrencilerin sosyal girişimcilik boyutlarından; risk alma boyutu ile ( $\mathrm{t}=-$ 3,0, $p=0,003$ ) cinsiyet arasında anlamlı farklılık bulunmuştur. Ortalamalara bakıldığında kadınların risk alma ortalamaları $(29,52 \pm 4,50)$, erkeklere $(27,64 \pm 4,98)$ göre daha yüksek çıkmıştır. Sosyal girişimcilik boyutlarından Özgüven boyutu $(t=0,62, p=0,530)$ ile Kişisel yaratıcılık boyutunun $(t=-0,60 p=0,950)$, cinsiyet değişkenine göre anlamlı farklıı̆ga rastlanmamıştır. Öğrencilerin sosyal girişimcilik

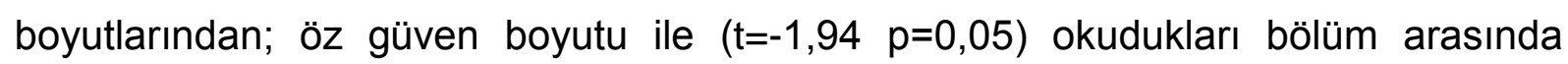
anlamlı farklıı̆ga bulunmamış ancak "p" değerinin 0,05'e çok yakın olduğu görülmektedir $(p=0,05)$. Bölüm ortalamalarına bakıldığında öğretmenlik bölümünde okuyan öğrencilerin özgüven ortalamaları $(31,36 \pm 5,32)$, antrenörlük bölümünde okuyan öğrencilere $(29,71 \pm 7,46)$ göre daha yüksek çıkmıştır. Sosyal girişimcilik boyutlarından risk alma boyutu ( $\mathrm{t}=-\mathrm{-}, 24, \mathrm{p}=0,81)$ ile kişisel yaratıcılık boyutunun $(\mathrm{t}=, 94$ $p=0,34)$, öğrencilerin okudukları bölüm değişkeni ile aralarında anlamlı farklıığa rastlanmamıştır.

Tablo 3. Öğrencilerin yaş ve sınıf değişkenine göre Sosyal Girişimcilik alt boyutlarına ilişkin Anova-testi sonuçları

\begin{tabular}{|c|c|c|c|c|c|c|c|c|c|c|c|c|c|}
\hline & \multicolumn{5}{|c|}{ Risk Alma } & \multicolumn{4}{|c|}{ Özgüven } & \multicolumn{4}{|c|}{ Kişisel Yaratıcılık } \\
\hline Yaş & $\mathbf{N}$ & $X$ & ss & $F$ & $p$ & $x$ & ss & $F$ & $p$ & $X$ & ss & $F$ & $p$ \\
\hline $18-20$ & 94 & 29.03 & 4.38 & & & 31.06 & 6.24 & & & 23.92 & 3.98 & & \\
\hline $21-25$ & 122 & 28.23 & 5.19 & .89 & 0.41 & 30.29 & 6.74 & .88 & 0.41 & 22.68 & 5.00 & 2.89 & 0.05 \\
\hline $26-30$ & 14 & 27.78 & 4.56 & & & 28.78 & 6.93 & & & 21.50 & 4.32 & & \\
\hline Sinıf & & & & & & & & & & & & & \\
\hline 1.sınıf & 71 & 28.22 & 4.82 & & & 29.52 & 4.01 & & & 23.23 & 4.16 & & \\
\hline 2.sinıf & 69 & 28.71 & 4.68 & 1.00 & 0.39 & 30.57 & 5.61 & .28 & 0.83 & 23.05 & 4.25 & .16 & 0.96 \\
\hline 3.sinıf & 48 & 27.87 & 5.68 & & & 30.08 & 7.07 & & & 22.77 & 6.23 & & \\
\hline 4.sinıf & 42 & 29.52 & 4.01 & & & 30.39 & 7.45 & & & 23.40 & 3.79 & & \\
\hline
\end{tabular}


Tablo 3'e göre Sosyal girişimcilik boyutlarından kişisel yaratıcılık boyutu ile yaş değişkeni arasında anlamlı farklılığa rastlanmamış $(F=2,89 p=0,05)$ ancak $p$ değerinin 0,05 'e çok yakın olduğu görülmektedir. Öğrencilerin sosyal girişimcilik alt boyutları olan risk alma $(F=.89, p=0,411)$; özgüven $(F=, 88, p=0,41)$ alt boyutları ile yaş değişkeni arasında anlamlı farklılığa rastlanmamıştır. Öğrencilerin sosyal girişimcilik alt boyutları olan risk alma $(F=1,00, p=0,39)$; özgüven $(F=, 28, p=0,83)$ ve kişisel yaratıcılık ( $F=, 16, p=0,96)$ alt boyutları ile sınıf değişkeni arasında anlamlı farklıı̆ğa rastlanmamıştır.

Tablo 4. Öğrencilerin anne eğitim durumlarına göre Sosyal Girişimcilik alt boyutlarına ilişkin Anova-testi sonuçları

\begin{tabular}{|c|c|c|c|c|c|c|c|c|}
\hline & Alt Boyut & Gruplar & $\mathbf{N}$ & $\overline{\boldsymbol{X}}$ & ss & $\mathbf{F}$ & $\mathbf{p}$ & fark \\
\hline \multirow{12}{*}{$\begin{array}{c}\text { Anne } \\
\text { Eğitim } \\
\text { Durumu }\end{array}$} & \multirow{4}{*}{ Risk Alma } & Ilköğretim & 134 & 29.02 & 4.51 & & & \multirow[t]{4}{*}{ 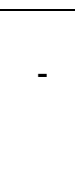 } \\
\hline & & Ortaokul & 54 & 27.50 & 4.15 & 1.42 & 0.230 & \\
\hline & & Lise & 24 & 28.62 & 7.47 & & & \\
\hline & & Üniversite & 18 & 27.83 & 4.57 & & & \\
\hline & \multirow{4}{*}{ Özgüven } & Ilköğretim & 134 & 30.94 & 6.00 & & & \multirow{4}{*}{$b>d$} \\
\hline & & Ortaokul & 54 & 31.44 & 4.97 & 5.07 & $0.001^{*}$ & \\
\hline & & Lise & 24 & 30.20 & 8.44 & & & \\
\hline & & Üniversite & 18 & 25.00 & 9.27 & & & \\
\hline & \multirow{4}{*}{$\begin{array}{c}\text { Kişisel } \\
\text { Yaratıcılık }\end{array}$} & Ilköğretim & 134 & 23.35 & 4.26 & & & \\
\hline & & Ortaokul & 54 & 23.11 & 4.56 & .47 & 0.700 & \\
\hline & & Lise & 24 & 22.29 & 6.11 & & & \\
\hline & & Üniversite & 18 & 22.50 & 5.18 & & & \\
\hline
\end{tabular}

${ }^{*} \mathrm{p}<0.05$ a: Ilköğretim, b: Ortaokul, c: Lise,d: Üniversite

Tablo 4'e göre Sosyal girişimcilik boyutlarından özgüven boyutu ile anne eğitim durumu değişkeni arasında $(F=5,07, p=0,001)$ anlamlı farklılık bulunmuştur. Farklılığın kaynağını bulmak için yapılan Bonferroni testi sonuçlarına göre anne eğitim durumu ortaokul olan öğrenciler ile anne eğitim durumu üniversite olan öğrenciler arasında çıkmıştır. Sosyal girişimcilik boyutlarından risk alma $(F=1.42$, $p=0,23)$ ve Kişisel Yaratıcılık $(F=.47, p=0,70)$ boyutları ile anne eğitim durumu değişkeni arasında anlamlı farklılığa rastlanmamıştır. 
Tablo 5. Öğrencilerin baba eğitim durumlarına göre Sosyal Girişimcilik alt boyutlarına ilişkin Anova-testi sonuçları

\begin{tabular}{|c|c|c|c|c|c|c|c|c|}
\hline & Alt Boyut & Gruplar & $\mathbf{N}$ & $\bar{X}$ & ss & $\mathbf{F}$ & $\mathbf{p}$ & fark \\
\hline \multirow{12}{*}{$\begin{array}{c}\text { Baba } \\
\text { Eğitim } \\
\text { Durumu }\end{array}$} & \multirow{4}{*}{ Risk Alma } & Ilköğretim & 87 & 29.49 & 4.08 & & & \multirow{4}{*}{$a>c ; a<d$} \\
\hline & & Ortaokul & 74 & 28.56 & 4.25 & 2.75 & $0.042^{*}$ & \\
\hline & & Lise & 48 & 27.16 & 5.81 & & & \\
\hline & & Üniversite & 21 & 27.57 & 6.46 & & & \\
\hline & \multirow{4}{*}{ Özgüven } & Ilköğretim & 87 & 30.28 & 6.12 & & & \multirow{4}{*}{ - } \\
\hline & & Ortaokul & 74 & 31.31 & 5.73 & .57 & 0.630 & \\
\hline & & Lise & 48 & 29.85 & 8.56 & & & \\
\hline & & Üniversite & 21 & 30.19 & 5.84 & & & \\
\hline & \multirow{4}{*}{$\begin{array}{c}\text { Kişisel } \\
\text { Yaratıcılık }\end{array}$} & Ilköğretim & 87 & 23.67 & 3.64 & & & \multirow{4}{*}{ - } \\
\hline & & Ortaokul & 74 & 22.94 & 4.39 & .80 & 0.490 & \\
\hline & & Lise & 48 & 22.72 & 5.89 & & & \\
\hline & & Üniversite & 21 & 22.28 & 5.64 & & & \\
\hline
\end{tabular}

${ }^{*} \mathrm{p}<0,05$ a: Ilköğretim, b: Ortaokul, c: Lise, d: Üniversite

Tablo 5'e göre sosyal girişimcilik boyutlarından risk alma ile baba eğitim durumu değişkeni arasında anlamlı farklılığa rastlanmıştır $(F=2,75 P=0,04)$. Bonferroni testi sonuçlarına göre farklılık baba eğitim düzeyi ilkokul olan öğrenciler ile eğitim düzeyi lise ve üniversite olanlar arasında çıkmıştır. Sosyal girişimcilik boyutlarından özgüven $(F=.57, p=0,63)$ ve Kişisel Yaratıcılık $(F=.80, p=0,49)$ boyutları ile baba eğitim durumu değişkeni arasında anlamlı farklılığa rastlanmamıştır.

\section{Tartışma ve Sonuç}

Bu çalışmada üniversite öğrencilerinin sosyal girişimcilik düzeylerini belirlemek ve sosyal girişimcilik alt boyutları olan; risk alma, özgüven ve kişisel yaratıcılık eğilimleri demografik değişkenler açısından incelenmiştir. Örneklemde yer alan BESYO öğrencilerinin sosyal girişimcilik eğilimlerinin olumlu düzeyde olduğu bulunmuştur. Sosyal girişimciliğe ilişkin yapılan araştırmalarda girişimci bireylerin yaratıcılık, risk alma, bağımsızlık isteği (Shahhosseini ve ark., 2011), başarma motivasyonu, kişisel yaratıcılık (Farzaneh ve ark., 2010) gibi özelliklere sahip oldukları ortaya konmuştur. Spor bölümü öğrencilerinin spora aktif olarak katıldıkları ve sporda edindikleri kazanımlardan dolayı bu tür girişimcilik özelliklerinin yüksek çıktığı söylenebilir.

Diğer bir sonuç olarak kadın ve erkek öğrenciler arasında risk alma boyutunda anlamlı farklılık ortaya çıkmıştır. Kadın öğrencilerin puan ortalamaları erkek öğrencilere göre yüksek çıkmıştır. Özmen (2015) spor bölümü öğrencileri üzerine yaptığı çalışmada kadın ve erkek öğrenciler arasında girişimcilik düzeyleri arasında farkılık bulunmamış fakat ortalamalara bakıldığında kadın öğrencilerin ortalamaları 
erkeklere göre daha "yüksek girişimcilik" düzeyinde olduğu bulunmuştur. Cansız (2007) yaptığı araştırmada ortalamaların yakın olmasına rağmen kadın öğrencilerin erkek öğrencilere göre girişimcilik düzeylerinin daha yüksek olduğunu bulmuştur. Buna karşın Wang ve Wong (2004) çalışmalarında erkek öğrencilerin girişimcilik seviyelerinin bayanlara göre yüksek olduğu sonucuna ulaşmıştır.

Şeşen ve Basım (2012) girişimcilik üzerine yaptıkları araştırmalarda erkek öğrencilerin girişimcilik düzeylerinin kadın öğrencilere göre daha yüksektir şeklindeki bulguları araştırmamızla tezatlık göstermektedir. Çavuş ve Pekkan (2017) üniversite öğrencilerinin girişimcilik düzeyleri üzerine yaptıkları çalışmada kadın ve erkek öğrencilerin girişimcilik algılarının farklılaşmadığı bulunmuştur. Öğretmenlik ve antrenörlük bölümü değişkenleri ile özgüven alt boyutu arasında farklılık bulunmamıştır. Fakat anlamlılık değeri olan $p$ değerinin 0,050 çok yakın olduğu görülmüş ve ortalamalara bakıldığında öğretmenlik bölümünde okuyan öğrencilerin özgüven ortalamaları antrenörlük bölümünde okuyan öğrencilerin ortalamalarından yüksek olduğu sonucu çıkmıştır. Bu durum öğretmenlik bölümünde okuyan öğrencilerin öğretmen olarak atanma durumlarından dolayı iş kaygılarının antrenörlük öğrencilerinden daha düşük olması ve bu sebepte özgüvenlerini antrenörlük bölüm öğrencilerine göre arttırdığı ile açıklanabilir. Aynı zamanda öğretmenlik bölümünün aldıkları eğitimle ilgili çeşitli alanlardaki yaptıkları staj uygulamaları ve aldıkları bölüm derslerinin öğrencilerinin girişimcilik düzeyleri üzerinde daha etkili olduğu söylenebilir. Karabulut ve ark., (2018) araştırmalarında spor yöneticiliği bölümünde okuyan öğrencilerin antrenörlük ve beden eğitimi ve spor öğretmenliği bölümünde okuyan öğrencilerden girişimcilik eğilimlerinin daha yüksek olduğu sonucuna ulaşırken; Cengiz ve ark., (2016) BESYO bölümleri üzerine yaptıkları çalışmada rekreasyon bölümünde okuyan öğrencilerin girişimcilik eğilimlerinin diğer bölümlerde okuyan öğrencilerden daha yüksek olduğu sonucuna ulaşmışlardır.

Özmen (2015) ise rekreasyon ve spor yöneticiliğinde öğrenim gören öğrencilere girişimcilik üzerine yaptıkları çalışma sonucunda bölüm değişkenine göre anlamlı farlılık bulunmamış ve girişimcilik düzeylerinin yüksek olduğu sonucuna ulaşmışlardır.

Yaş değişkeni ile kişisel yaratıcılık boyutu arasında farklılık bulunmuştur. Yaşları 18-20 arasında olan öğrencilerin kişisel yaratıcılık puanı yaşları 26-30 arasındaki öğrencilerden yüksek çıkmıştır. Literatürde çoğunlukla 22-25 yaş arası girişimcilik kariyerine başlama dönemi olarak ortaya konmuştur. Bu sonuca dayalı 
olarak yaşları daha küçük olan öğrencilerin kişisel yaratıcılık düzeylerinin yüksek çıktığı söylenebilir. Özman (2013) yaptığı araştırma sonucunda yaş ilerledikçe girişimcilik düzeyinin azaldığı sonucunu bulmuştur. Ceviz ve ark. (2016) üniversite öğrencilerinin girişimcilik düzeylerini belirlemeye yönelik yaptıkları araştırma sonucuna göre genç katılımcıların (17-20 yaş) yeni fikirlere daha açık ve daha girişimci bir potansiyele sahip olduklarını ve yaş arttıkça girişimcilik eğilimlerinin azaldığı sonucuna ulaşmıştır Şeşen ve ark. (2012) yapmış olduğu araştırmada genç yaştaki öğrencilerin girişimcilik düzeyleri, ileri yaştaki öğrencilerden daha düşük çıktığı sonucuna ulaşmıştır. Aynı zamanda anne ve baba eğitim düzeyine göre öğrencilerin sosyal girişimcilik düzeyleri alt boyutlarında farklılık bulunmuştur. Gaddam, (2007) sosyal girişimciliği etkileyen en önemli değişkenlerin yaş, deneyim ve eğitim seviyesi olduğunu çalışmalarında ileri sürmüştür.

Sonuç olarak, sosyal girişimcilik eğitiminin amacı sosyal sorunlara duyarlı, empati yapabilen, yenilikçi ve girişimci kendini gerçekleştirme arzusu olan bireyler yetiştirmektir. Öğretmenlik ve antrenörlük bölümü öğrencilerinin gelecekte yetiştirecekleri öğretmen ve sporculara daha etkin ve verimli katkılar sağlamaları açısından öğrenim gördükleri süre içerisinde öğrendiklerini uygulamaya dökecek girişimcilik ile ilgili yeni öğretim ve öğrenme stratejileri geliştirilmesinin öğrencilere katkı sağlayacağı ve sosyal girişimci kişilik özelliklerini (risk alma, özgüven, kişisel yaratıcılık) geliştirecektir. Yapılan literatür araştırması sonucunda Keat ve ark (2011); İbicioğlu, Taş ve Özmen (2010) yaptıkları araştırmalarda girişimcilik eğitimi almanın girişimcilik düzeyine anlamlı sonuçlar kattığını belirlemişlerdir. Smith ve Steward (2010), sporun ayırt edici özelliklerinin spor işletmeleri üzerinde önemli bir etkisi olduğunu belirtmiştir. Bu özellikten dolayı BESYO öğrencilerinin üniversite eğitimi sonrasındaki hayatlarında kendi işlerini kurma, yönetme becerileri, spor organizasyonları geliştirme ve sosyal girişimciliklerinin geliştirilmesi spor sektörü açısından da faydalı olacaktır. Kamu ve sosyal hizmetlerin geliştirilmesi konusunda yeni yollar öneren, bireylerin gönüllü kuruluşlara katılmasını ve gönüllü olarak çalışmasını destekleyen, sosyal sorunları çözebilmek için var olan kaynakların daha etkili bir şekilde kullanılmasını gibi faydalar sağlayan sosyal girişimciliğin, özellikle üniversite öğrencilerinin ilgi odağı olması ülkenin geleceği içinde çok büyük faydalar sağlayacaktır. 
Ek olarak sosyal girişimcilik düzeylerinin geliştirilmesi sonucunda öğrencilerin kamu odaklı iş beklentisini azaltarak özel sektör odaklı iş beklentisi veya iş kurma fikrini arttıracaktır. Aynı zamanda beden eğitimi ve spor yüksekokullarının diğer bölümleri olan spor yöneticiliği ve rekreasyon bölümü öğrencilerine de sosyal girişimcilik eğilimlerinin belirlenmesine yönelik çalışmaların yapılması konuyla ilgili daha geniş bir bakış açısı sağlayacaktır.

\section{Kaynaklar}

Baron, R. A. (2004). The cognitive perspective: a valuable tool for answering entrepreneurship's basic "why" questions. Journal of Business Venturing, 19(2): 221-239.

Brown, U. J., Beale, R. L. \& White-Johnson, S. (2011). Perceptions of entrepreneurial intentions and risk propensity: self reliance and self efficacy in college students to encourage knowledge. Review of Business Research, 11(5): 169-77.

Cansız, E. (2007). Üniversite Öğrencilerinin Girişimcilik Özelliklerinin Belirlenmesi. Süleyman Demirel Üniversitesi Örneği. Yüksek Lisans Tezi, Isparta: Süleyman Demirel Üniversitesi.

Cengiz, R., Serdar, E., \& Donuk, B. (2016). Analyzing the level of mindfulness and entrepreneurship of the university students. International Journal of Social Sciences and Education Research, 2(4): 1321-1328

Ceviz Ö.N., TEKTAŞ M., Yayla A.İ., Polat Z. (2016). Meslek yüksekokullarında öğrenim gören gençlerin girişimcilik eğilimleri üzerine bir araştırma. Eğitim ve Öğretim Araştırmaları Dergisi. 5 (37): 319-331.

Çavuş, M. F., \& Pekkan N. Ü. (2017). Algılanan sosyal desteğin sosyal girişimciliğe etkisi: Üniversite öğrencileri üzerinde bir araştırma. Business and Economics Research Journal, 8(3): 519-532.

Çoşkun E., \& Sarıkaya M. (2016). Sosyal girişimcilik eğitiminde gönüllü kuruluşlar, Strategic Public Management Journal, (4): 72-82.

Denizalp, H. (2009). Toplumsal Dönüşüm için Sosyal Girişimcilik Rehberi (2. Baskı). Ankara: Sivil Toplum Geliştirme Merkezi Yayını, Odak Ofset Matbaacılık.

Dilsiz A., Kölük M. (2008). Girişimcilik. Ankara: Detay Yayıncılık. 
Erdoğan, D. G., Ekşioğlu, S., Gunes, D. Z. \& Gultekin, G. Z. (2014). The relationship between social entrepreneurship characteristics and the personal innovativeness of prospective teachers. Anthropologist, 18(3): 727-733.

Farzaneh, G., Hassan, A., Gholamreza, P., Mirsalaldin, E., Parviz, A, \& Alireza, H. (2010). Relationship between creativity, grade point average, achievement motivation, age and entrepreneurship among university students. Australian Journal of Basic and Applied Sciences, 4 (10): 5372-5378.

Gaddam, S. (2007). A conceptual analysis of factors influencing entrepreneurship behavior and actions. ICFAI Journal of Management Research, 6(11), ss:46-63

Gartner W. (1988).Who is an entrepreneur? Is the wrong question. American Journal of Small Business, 12(4): 11-32.

Geri, S. (2013). Research on entrepreneurial characteristics of students in school of physical education and sports. Turkish Journal of Education 2(3): 50-60

Gusseinova, D. (2015). Sosyal girişimcilik olgusu ve bir örnek olay incelemesi. Sosyal Bilimler Enstitüsü, Yüksek Lisans Tezi, İzmir: Dokuz Eylül Üniversitesi.

Güler K. B. (2010). Sosyal Girişimcilik. Ankara: Elif Yayınevi.

Güven, S. (2013). Sosyal etki yaratmak. Optimist: Sosyal inovasyon makaleleri, Standford Social Innovation Review, 10.Yıl Özel Sayısı, 4-5.

İbicioğlu, H., Taş, S., \& Özmen H. G. (2010). Üniversite eğitiminin girişimcilik düşüncesinin değişimine etkisi: Üniversite öğrencileri üzerine bir uygulama. Alanya Işletme Fakültesi Dergisi, 2(1): 53-74.

İşcan, Ö.F. \& Kaygın, E. (2011). Üniversite öğrencilerinin girişimcilik eğilimlerini belirlemeye yönelik bir araştırma. Atatürk Üniversitesi Sosyal Bilimler Enstitüsü Dergisi, 15 (2): 443-462.

Jana, N. (2015). Developing the entrepreneurial competencies of sport management students. Procedia - Social and Behavioral Sciences, 174: 3916-3924.

Karabulut, E.O., \& Doğan, P.K. (2018). Investigation of entrepreneurship trends and general competency levels of university students studying at faculty of sports sciences. Journal of Education and Training Studies, 6(4): 212-220.

Keat Y., Selvarajah C., \& Meyer. D. (2011). Inlination towards entrepreneurship among university students: an empirical study of Malaysian University students. International Journal of Business and Social Science, 4: 206-220. 
Koçak, O., \& Kavi, E. (2014). Sosyal politika aktörü olarak sosyal girişimci belediyecilik. Hak-Iş Uluslararası Emek ve Toplum Dergisi, 3(6): 26-49.

Konakli, T., \& Göğüş, N. (2013). Pre-service teachers' social qualifications scale: validity and reliability study. Gazi University Journal of Gazi Educational Faculty, 33(2): 373-391.

Liñán, F. \& Chen, Y. (2009). Development and cross-cultural application of a specific instrument to measure entrepreneurial intentions. Entrepreneurship Theory and Practice, 33(3): 593-617.

Özdevecioğlu, M. ve Cingöz, A. (2009). Sosyal Girişimcilik ve Sosyal Girişimciler: Teorik Çerçeve. Erciyes Üniversitesi İktisadi ve İdari Bilimler Fakültesi Dergisi, 32(82) 81-95

Özman, C. (2013). Spor Yöneticiliği Bölümünde Öğrenim Gören Üniversite Öğrencilerinin Girişimcilik Düzeylerinin Belirlenmesi. Yüksek Lisans Tezi, İstanbul: Marmara Üniversitesi.

Özmen, Ç. (2015). Rekreasyon ve Spor Yöneticiliği Bölümü Öğrencilerin Girişimcilik Düzeylerinin Değerlendirilmesine Yönelik bir Çalışma. Yüksek Lisans Tezi, Burdur. Mehmet Akif Ersoy Üniversitesi.

Shahhosseini, A., Kavousy, E., Shirsavar, H. R., \& Ardahaey, F. T. (2011). Appointing the level of individual entrepreneurship of Islamic Azad University students. Asian Social Science, 7(1): 106-114.

Smith, A. C., \& Stewart, B. (2010). The special features of sport: A critical revisit. Sport Management Review, 10(1): 1-11

Şeşen, H, \& Basım N. (2012). Demografik faktörler ve kişiliğin girişimcilik niyetine etkisi: Spor bilimleri alanında öğrenim gören üniversite öğrencileri üzerine bir araştırma. Ege Akademik Bakış, 12: 21-28.

Uluyol, O. (2013). Öğrencilerin girişimcilik eğilimlerinin belirlenmesi: Gölbaşı meslek yüksekokulu örneği. Adıyaman Üniversitesi Sosyal Bilimler Enstitüsü Dergisi, 6(15).

Yılmaz E. \& Sünbül A. M. (2009). Üniversite Öğrencilerine Yönelik Girişimcilik Ölçeğinin Geliştirilmesi, Selçuk Üniversitesi Sosyal Bilimler Enstitüsü Dergisi, 21: 195-203. 